\title{
Structural Determinants of the Total Loans Volume in the Czech Republic ${ }^{\#}$
}

\author{
Iveta $\check{R} E P K O V A A^{*}$
}

\section{Introduction}

The evolution of bank lending theoretically results from the interaction between demand and supply factors. However, the variables that help to explain the dynamics of the loans sometimes affect both demand for and supply of credit, and it is not always possible to empirically identify the two channels. There are usually variables of scale, variables related to financing conditions, variables related to the position of households and corporations and factors related to structural changes in the banking sector and other variables (Castro - Santos, 2010, p. 69).

In the Czech Republic there is the lack of studies examining the influence of the structural characteristics on total loans volume in the Czech banking sector, therefore it offers opportunity for this research. The determinants of the credit growth research following studies. Hampl and Matoušek (2000) examined the impact of the supply side aspects on the total loans. Buchtíková (2001) examined the impact of microeconomic aspects on the total loans in the Czech Republic in the period 1995-1999, where she distinguished among the effects of loans for household, private and public companies. The study observed the maximum impact of changes of interest rates on loans for foreign enterprises, whilst the lowest impact on the loans for state enterprises. Pašaličová and Stiller (2002) performed an analysis of the impact of monetary policy on the total loans volume and the impact of the elasticity of total loans on the real output of the economy. They did not find the elasticity between the total loans volume and the interest rates, but they confirmed the inversely proportional

\footnotetext{
\# The article is processed as an output of a research project Financial integration in the $E U$ and its effect on corporate sector registered by the Student Grant Competition of Silesian University under the registration number SGS 25/2010.

Ing. Iveta Řepková - Ph.D. student; Department of Finance at Silesian University in Opava, School of Business Administration in Karviná, Univerzitní náměstí 1934/3, 73340 Karviná, Czech Republic; <repkova@opf.slu.cz>.
} 
relationship between lending interest rate of commercial banks and loans to households.

The aim of this paper is to analyze the structural determinants of the total loans volume in the Czech banking sector. The impact of five selected characteristics on total loans volume will be examined. Structural characteristics of the banking sector includes the concentration of the credit market $(C R)$, the profitability of the banking sector calculated as the return on assets $(R O A)$, the share of the interest income to total income (IITI), the quality of the credit portfolio (NP) and the interest rate (REPO). Analysis of the Czech banking sector is realized in period 2000-2008.

The next part presents the data and describes the variables used; it also describes my opinion of expected impact of structural characteristics on total loans volume. Next, there is the specification of model and result of the empirical estimation. The paper ends with summary and conclusion.

\section{Data and model specification}

We used quarterly data from 2000:1 to 2008:4 for the Czech banking sector obtained from the Czech National Bank (CNB).

Concentration of the banking sector is measured by indicators of the concentration ratio (CR). $C R$ takes the market shares of the $k$ largest banks in the market and ignores the remaining banks in that market. This index is based on the idea that the behaviour of a market is dominated by a small number of large banks (Bikker - Haaf, 2001, p. 18). Summing over the market shares of the $k$ largest banks in the market, it takes the form:

$$
C R_{k}=\sum_{i=1}^{k} s_{i},
$$

There is no rule for the determination of the value of $k$, so that the number of banks included in the concentration index is a rather an arbitrary decision. The concentration ratio may be considered as one point on the concentration curve, and it is a one-dimensional measure ranging between zero and unity. The index approaches zero for an infinite number of equally sized banks and it equals unity if the banks included in the calculation of the concentration ratio make up the entire industry (Bikker - Haaf, 2000, p. 6). 
The quality of credit portfolio is expressed as percentage of the classified loans to the total loans. Classified loans represent a total volume of claims, which are at risk of repayment. Classified loans are receivables those repayment is jeopardised. Classified loans represent a potential threat to a bank; they require the creation of provisions, which a bank must use to cover the depreciation of its loan portfolio, thereby decrease the bank's profits (ČNB, 2010a). Classified loans comprise watch loans, substandard loans, doubtful loans and loss loans.

Profitability of the banking sector will be measured by indicator Return on Assets (ROA), which is determined as total profit (loss) after tax to total assets. ${ }^{1}$ This percentage measures profitability by expressing the efficiency of asset utilization. ROA is an indicator of how profitable a company is relative to its total assets.

Share of interest income to total income consists of share between interest income and income from banking activities, the share between difference between the interest income and costs and the difference between other income and other costs.

Interest rate is determined as two-week REPO, which represent an official CNB's interest rate. I used this interest rate of the end of month.

The elementary descriptive statistics is presented in Table 1 .

Tab. 1: Descriptive statistics

\begin{tabular}{|l|r|r|r|c|c|c|}
\cline { 2 - 8 } \multicolumn{1}{c|}{} & LOAN & \multicolumn{1}{c}{ CR } & \multicolumn{1}{c|}{ NP } & ROA & IITI & REPO \\
\hline Mean & 0.0102 & -0.0041 & -0.0404 & 0.0290 & 4.1324 & -0.0242 \\
\hline Median & 0.0069 & 0.0000 & -0.0280 & 0.0000 & 4.1034 & 0.0000 \\
\hline Maximum & 0.1576 & 0.1294 & 0.1360 & 0.8247 & 4.4639 & 0.2231 \\
\hline Minimum & -0.1165 & -0.1029 & -0.3952 & -0.2355 & 4.0481 & -0.4418 \\
\hline Std. Dev. & 0.0418 & 0.0313 & 0.0942 & 0.1996 & 0.0810 & 0.1246 \\
\hline Skewness & 0.4850 & 1.1465 & -1.9063 & 2.1831 & 2.1811 & -0.9568 \\
\hline Kurtosis & 7.8696 & 13.391 & 8.0738 & 8.8453 & 9.0572 & 5.2572 \\
\hline Jarque-Bera & 35.953 & 165.14 & 58.741 & 77.628 & 81.257 & 12.770 \\
\hline
\end{tabular}

1 Methodology according to the $\breve{C} N B(2010 b)$ is used. 


\begin{tabular}{|l|c|c|c|c|c|c|}
\cline { 2 - 7 } \multicolumn{1}{c|}{} & LOAN & CR & NP & ROA & IITI & REPO \\
\hline Probability & 0.0000 & 0.0000 & 0.0000 & 0.0000 & 0.0000 & 0.0017 \\
\hline Observations & 35 & 35 & 35 & 35 & 35 & 35 \\
\hline
\end{tabular}

Source: Author's calculations based on data from ČNB (2010b)

\section{Expected impact of characteristics on total loans volume}

Between profitability and lending we expect a positive relationship. Low profitability of banks leads to their lower stability and reduces their competitiveness and limits the supply of products on the financial market (Niedermayer, 2001). Growth of classified loans has a negative influence on the amount of granted loans. Decreasing share of the classified loans to total loans has a positive impact on the growth of total loans. We suppose the concentration of the credit market positively influences the lending transactions. On the more concentrated market we expect a higher growth of loans granted, because larger banks have enough resources for funding. The share of interest income to total income of banking services is likely to have a positive influence on the total credits. In our opinion there is a negative relationship between the interest rate and total loans. When the interest rate declines consumers increase the demand for loans.

\section{Model specification}

The application part of the paper examines, whether individual characteristics of the banking sector have an impact on total loans volume. To determinate the impact of each variable to total loans volume the regression analysis is used:

$$
\begin{aligned}
\ln L O A N_{t}= & \beta_{0}+\beta_{1} \ln I I T I_{t}+\beta_{2} \ln N P_{t}+\beta_{3} \ln C R_{t}+\beta_{4} \ln R O A_{t} \\
& +\beta_{5} \ln R E P O_{t}+\varepsilon_{t}
\end{aligned}
$$

where $L O A N_{t}=$ total loans volume,

${I I T I_{t}}=$ share of interest income to total income,

$N P_{t} \quad=$ share of classified loans to total loans,

$C R_{t} \quad=$ concentration of credit market,

$R O A_{t}=$ return of assets,

$R E P O_{t}=$ interest rate. 


\section{Empirical results}

Before estimating the model we tested the time series for the stationarity. We applied Augmented Dickey-Fuller (ADF) test (Dickey Fuller, 1979) and the Phillips-Perron (PP) test (Phillips - Perron, 1988) to test the individual variables for the existence of the unit roots. For this test, the null hypothesis is that the time series contains a unit root (not stationary). If we are able to reject the null hypothesis, we conclude that the time series is stationary. Both ADF and PP test indicates the variables are non-stationary on the values so that the null hypothesis of a unit root cannot be rejected for any of the series. Testing variables on the first differences indicates the time series are stationary so that we made difference the first difference the variables to achieve stationarity. Now, all times series are stationary and can be used in regression analysis.

The method applied to estimate of equation (2) is Ordinary Least Squares (OLS). For correction of heteroscedasticity is used White test, which is a standard approach test according to White (1980). Heteroscedasticity can be rejected according to White test.

For detecting multicollinearity we used correlation coefficient, which shows relationships between variables. Correlation matrix is presented in Table 2. From the correlation matrix it is obvious that any variables are not correlated together.

Tab. 2: Correlation matrix

\begin{tabular}{|l|r|r|r|r|r|r|}
\cline { 2 - 8 } \multicolumn{1}{c|}{} & \multicolumn{1}{c|}{ LOAN } & \multicolumn{1}{c|}{ CR } & \multicolumn{1}{c|}{ NP } & \multicolumn{1}{c|}{ ROA } & \multicolumn{1}{c|}{ IITI } & \multicolumn{1}{c|}{ REPO } \\
\hline LOAN & 1.0000 & 0.5799 & -0.0928 & 0.1899 & -0.0644 & -0.0016 \\
\hline CR & 0.5799 & 1.0000 & 0.3317 & -0.1895 & -0.0139 & 0.0220 \\
\hline NP & -0.0928 & 0.3317 & 1.0000 & -0.4447 & 0.2180 & -0.0810 \\
\hline ROA & 0.1899 & -0.1895 & -0.4447 & 1.0000 & -0.0389 & -0.0627 \\
\hline IITI & -0.0644 & -0.0139 & 0.2180 & -0.0389 & 1.0000 & -0.0467 \\
\hline REPO & -0.0016 & 0.0220 & -0.0810 & -0.0627 & -0.0467 & 1.0000 \\
\hline
\end{tabular}

Source: Author's calculations

Using ordinary least squares regression analysis in EViews is estimated of equation (2) to determine the impact of five selected 
characteristic of the banking sector on total loans volume. The regression results of equation (2) are presented in Table 3 and Table 4.

Tab. 3: Regression results

\begin{tabular}{|c|c|c||c|c|c|}
\hline Variable & Coefficient & t-Statistic & Variable & Coefficient & t-Statistic \\
\hline \multirow{2}{*}{$C$} & 0.002320 & 0.007760 & $R O A$ & 0.045876 & 1.434317 \\
\cline { 2 - 3 } & $(0.9939)$ & & & $(0.1622)$ & \\
\hline \multirow{2}{*}{$C R$} & 0.932092 & 4.828725 & $I I T I$ & 0.001467 & 0.020326 \\
\cline { 5 - 6 } & $(0.0000)$ & & & $(0.9839)$ & \\
\hline \multirow{2}{*}{$N P$} & -0.101840 & -1.401834 & $R E P O$ & -0.007290 & -0.158556 \\
\cline { 2 - 3 } & $(0.1716)$ & & & $(0.8751)$ & \\
\hline
\end{tabular}

Source: Author's calculations

Note: Probability is presented in parentheses.

Table 3 shows that the concentration, the profitability and the share of interest income to total income has positive impact to total loans. The quality of portfolio and interest rate has negative impact to total loans. We applied redundant variables test - Likehood Ratio, which confirms that the interest rate and the share of interest income to total income are not significant for this model and therefore can be excluded from the final model. Adjusted estimation of equation is presented in Table 4.

Tab. 4: Regression results

\begin{tabular}{|c|c|c||c|c|c|}
\hline Variable & Coefficient & t-Statistic & Variable & Coefficient & t-Statistic \\
\hline \multirow{2}{*}{$C$} & 0.008608 & 1.458519 & $N P$ & -0.100032 & -1.476910 \\
\cline { 2 - 3 } \cline { 5 - 6 } & $(0.1548)$ & & & $(0.1498)$ & \\
\hline \multirow{2}{*}{$C R$} & 0.930308 & 5.006357 & $R O A$ & 0.046464 & 1.512892 \\
\cline { 2 - 3 } & $(0.0000)$ & & & $(0.1404)$ & \\
\hline \multicolumn{2}{|c|}{$\mathrm{R}^{2}=0.4670$, Prob(F-stat. $)=0.0002, \mathrm{DW}=2.0037$} \\
\hline
\end{tabular}

Source: Author's calculations

Note: Probability is presented in parentheses. 
Table 4 presents result of the regression analysis, where we can see that the concentration and the profitability has positive impact to total loans and quality of portfolio has negative impact to total loans. If the share of classified loans to total loans is decreasing, total loans volume is rising and if the concentration ratio of the credit market and return of assets are rising, total loans volume is also rising.

\section{Conclusion}

The aim of this paper was to analyze the structural determinants of the total loans volume in the Czech banking sector. The analysis was made in the Czech Republic in period 2000-2008. We examined the impact of five structural characteristics on total loans volume. Selected variables include the concentration of the credit market, the profitability of the banking sector calculated as the return on assets (ROA), the share of interest income to total income, the quality of portfolio calculated as the share of classified loans to total loans and the interest rate. We used the Ordinary least squares regression analysis for estimate of model. The regression analysis showed that, in the analyzed period, the concentration of the credit market and ROA has positive impact to total loans and the quality of portfolio has negative impact to total loans. If the share of classified loans to total loans is decreasing, total loans volume is rising and if the concentration ratio of the credit market and return of assets are rising, total loans volume are also rising. Two variables, the interest rate and the share of interest income to total income, were excluded from the final model, because redundant variables test - Likehood ratio confirms, that these variables are not significant for the model.

\section{References}

[1] Bikker, J. A. - Haaf, K. (2000): Measures of competition and concentration in the banking industry: a review of the literature. Amsterdam, De Nederlandsche Bank, 2000.

[2] Bikker, J. A. - Haaf, K. (2001): Competition, Concentration and their Relationship: An Empirical Analysis of the Banking Industry. Amsterdam, De Nederlandsche Bank, 2001.

[3] Buchtíková, A. (2001): Mikroekonomické aspekty transmisního mechanismu ménové politiky v úvěrovém kanále (empirická studie). Praha, Česká národní banka, 2001. 
[4] Castro, G. - Santos, C. (2010): Bank Interest Rates and Loans Determinants. Lisboa, Banco de Portugal, 2010, p. 65-86.

[5] ČNB (2010a): Classified Loans. [on-line], Praha, Czech National Bank, c2010, [cit. $3^{\text {rd }}$ April 2010], <http://www.cnb.cz/cs/obecne/slovnik/k.html>.

[6] ČNB (2010b): Financial Stability Reports 2004-2009. [on-line], Praha, Czech National Bank, c2010, [cit. $3^{\text {rd }}$ April 2010], <http://www.cnb.cz/en/financial_stability/fs_reports/index.html>.

[7] Dickey, D. A. - Fuller, W. A. (1979): Distribution of the Estimators for Autoregressive Time Series with a Unit Root. Journal of the American Statistical Association, 1979, vol. 74, no. 366, pp. 427-431.

[8] Hampl, M. - Matoušek, R. (2002): Úvěrová kontrakce v ČR - její príćciny a důsledky. Praha, Czech National Bank, 2000.

[9] Niedermayer, L. (2001): Nizký růst úvěrů postihuje malé a střední podniky. [on-line], Praha, Hospodářské noviny 21. 2. 2001, s. 16, [cit. $24^{\text {th }}$ April 2010],

<http://www.cnb.cz/cs/verejnost/pro_media/clanky_rozhovory/media _2001/cl_01_010221.html>.

[10] Pašaličová, R. - Stiller, V. (2002): Vliv měnové politiky na vývoj bankovních úvěrů. Finance a úvěr, 2002, vol. 52, no. 6, pp. 338-354.

[11] Phillips, P. C. B. - Perron, P. (1988): Testing for a Unit Root in Time Series Regression. Biometrika, 1988, vol. 75, no. 2, pp. 335-346.

[12] White, H. (1980): A Heteroskedastic-consistent Covariance Matrix Estimator and a Direct test of Heteroskedasticity. Econometrica, 1980, vol. 48 , no. 4, 817-838. 


\title{
Structural Determinants of the Total Loans Volume in the Czech Republic
}

\author{
Iveta ŘEPKOVÁ
}

\begin{abstract}
The aim of this paper is to analyze the structural determinants of the total loans volume in the Czech banking sector. Analysis of five selected characteristics is realized in period 2000-2008. It used the OLS regression analysis for estimate of model. The regression analysis showed that the concentration of the credit market and the profitability calculated as the return on assets (ROA) has positive impact to total loans and the quality of portfolio has negative impact to total loans. If the share of classified loans to total loans is decreasing, total loans volume is rising and if concentration ratio of the credit market and return of assets are rising, total loans volume is also rising.

Key words: Banking sector; Total loans; Concentration; Interest rate; Profitability; Return on Assets (ROA); Regression analysis; Ordinary least squares (OLS).
\end{abstract}

JEL classification: $\mathrm{C} 58, \mathrm{G} 21$. 